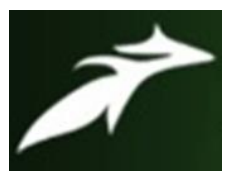

Ku. Sakshee Yadav et al, International Journal of Advances in Agricultural Science \& Technology,

Vol.8 Issue.11, November-2021, pg. 60-69

ISSN: 2348-1358

Impact Factor: 6.057

NAAS Rating: 3.77

\title{
Impact of Vocational Training Programme toward Rural Women Conducted by KVK in Korea District of Chhattisgarh
}

\author{
Ku. Sakshee Yadav; Dipak Kumar Bose; Jahanara \\ MSc.Ag; Associate Professor; Professor and Head \\ Department of Agricultural Extension and Communication, SHUATS, Prayagraj
}

DOI: 10.47856/ijaast.2021.v08i11.007

\begin{abstract}
KVKs impart trainings and education with a view to raise the level of knowledge, attitudinal changes and testing and transferring of recommended improved farm technologies so as to bridge the gap between production and productivity and also to increase self-employment opportunities among the farming community. Rural Women in India, contributing $25 \%$ of GDP, is increasingly becoming a Female Activity. The present study was an attempt to evaluate the impact of training on its beneficiaries with reference to know the extent of success in raising the income of beneficiaries. For attaining the objectives, the present investigation was carried out in Baikunthpur block of Koriya district, Chhattisgarh. A total of 60 trainees and 60 non-trainees were selected as sample for the study. The data were collected by personal interview with the help of structured and pre-tested schedule. Percentage and other statistical tools were used to analyze the data. Age, educational status, land holding, number of training attended and progressiveness had significant relation with income and employment generation. Size of family, occupation, annual income, extension participation and risk bearing capacity had non-significant relation with income and employment generation.
\end{abstract}

Keywords: Vocational Training, KVK and Income generation.

\section{Introduction:}

In the strategy of women empowerment, a great emphasis is placed on education, economic independence and rights of women (Pandey 2017). For economic independence, vocational training may become very effective tool to empower women. For this purpose, training centers have been set up all over the country stated earlier, when training programmes of greater magnitude have undertaken, it called for the scientific research with reference to each aspect of the training programme. Training has become a very important aspect of new strategy; hence it calls for many adjustments, both on the part of the participants in the training and also on the part of the organization responsible for the training (Singh et.al, 2018). The Krishi Vigyan Kendras are the grass-root level technology transfer and vocational training institutions designed 


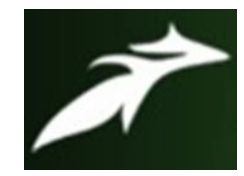

Ku. Sakshee Yadav et al, International Journal of Advances in Agricultural Science \& Technology, Vol.8 Issue.11, November-2021, pg. 60-69

ISSN: 2348-1358

Impact Factor: 6.057

NAAS Rating: 3.77

for bridging the gap between technologies on one hand and their application for increased production on the other (Panwar, 2018). KVKs impart trainings and education with a view to raise the level of knowledge, attitudinal changes and testing and transferring of recommended improved farm technologies so as to bridge the gap between production and productivity and also to increase self-employment opportunities among the farming community (Sunil, 2010). The training programmes (on- or off campus) of KVKs are being conducted for fulfilling the KVK mandate. Training to farmers encompasses all the roles of a farmer instead of looking at him only as a producer. The training programmes are planned so as to meet the immediate requirements of the farming community.

Rural Women in India, contributing $25 \%$ of GDP, is increasingly becoming a Female Activity. Forty eight per cent of India's self-employed farmers are women (Manoj Kaur et.al, 2019). They utilize all their mind power by use of new techniques and also make themselves self-dependent and capable. A self-dependent woman can take their own decision related to their works and health (Santhi P et.al, 2013). Training has been acclaimed as an effective tool to develop, the quality of human resources, to gain confidence and improve capability of individuals in relation to their needs and requirements. The present study was an attempt to evaluate the impact of training on its beneficiaries with reference to know the extent of success in raising the income of beneficiaries and level of employment generation with following objectives, to know the socio-economic profile of the respondents; and to find out the impact of vocational training programme on employment and income generation of rural women.

\section{Methodology:}

There are 22 Krishi Vigyan Kendras in Chhattisgarh. All 22 KVK's comes under organization of IGKV. One Krishi Vigyan Kendra i.e. Koriya is selected purposively for the present study because the KVK Koriya has adopted five clusters of villages, for dissemination of technologies related to income and employment generating thought trainings. The list of beneficiaries who had been attended the training programme was obtained from the KVK 


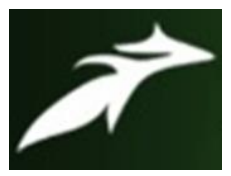

Ku. Sakshee Yadav et al, International Journal of Advances in Agricultural Science \& Technology,

Vol.8 Issue.11, November-2021, pg. 60-69

ISSN: 2348-1358

Impact Factor: 6.057

NAAS Rating: 3.77

Koriya, out of total 60 trainee and 60 non-trainee were selected from each selected villages by random sampling method. The data were collected by personal interview with the help of structured and pre-tested interview schedule. Percentage and other statistical tools were used to analyze the data.

\section{Results and Discussion:}

Table 01: Socio-Economic profile characters of the respondents

\begin{tabular}{|c|c|c|c|c|c|c|}
\hline \multirow{2}{*}{$\begin{array}{l}\text { S. } \\
\text { No. }\end{array}$} & \multirow[t]{2}{*}{ Variable } & \multirow[t]{2}{*}{ Category } & \multicolumn{2}{|c|}{ Trainee $(n=60)$} & \multicolumn{2}{|c|}{ Non-Trainee $(n=60)$} \\
\hline & & & Frequency & Percentage & Frequency & Percentage \\
\hline \multirow{3}{*}{1.} & \multirow{3}{*}{ Age } & $\begin{array}{l}\text { Young } \quad(<27 \\
\text { years })\end{array}$ & 16 & 26.67 & 11 & 18.33 \\
\hline & & $\begin{array}{l}\text { Middle } \quad(27-46 \\
\text { years })\end{array}$ & 29 & 48.33 & 30 & 50.00 \\
\hline & & Old (>46 years) & 15 & 25.00 & 19 & 31.67 \\
\hline \multirow{5}{*}{2.} & \multirow{5}{*}{ Education } & Illiterate & 10 & 16.67 & 21 & 35.00 \\
\hline & & Primary & 12 & 20.00 & 11 & 18.33 \\
\hline & & Middle & 21 & 35.00 & 15 & 25.00 \\
\hline & & Higher secondary & 14 & 23.33 & 09 & 15.00 \\
\hline & & Graduate & 03 & 05.00 & 04 & 06.67 \\
\hline \multirow{4}{*}{3.} & \multirow{4}{*}{ Landholding } & Marginal farmers & 34 & 56.67 & 30 & 50.00 \\
\hline & & Small farmers & 15 & 25.00 & 12 & 20.00 \\
\hline & & Medium farmers & 6 & 10.00 & 11 & 18.33 \\
\hline & & Large farmers & 1 & 00.83 & 1 & 00.83 \\
\hline 4. & Size of Family & Small & 04 & 06.67 & 06 & 10.00 \\
\hline
\end{tabular}




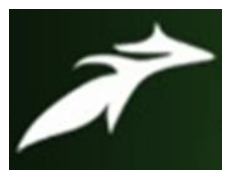

Ku. Sakshee Yadav et al, International Journal of Advances in Agricultural Science \& Technology, Vol.8 Issue.11, November-2021, pg. 60-69

ISSN: 2348-1358

Impact Factor: 6.057

NAAS Rating: 3.77

\begin{tabular}{|c|c|c|c|c|c|c|}
\hline & & Medium & 44 & 73.33 & 48 & 80.00 \\
\hline & & Large & 12 & 20.00 & 06 & 10.00 \\
\hline & & Agriculture alone & 44 & 73.33 & 51 & 85.00 \\
\hline & & $\begin{array}{l}\text { Agriculture + } \\
\text { Business }\end{array}$ & 03 & 05.00 & 03 & 05.00 \\
\hline 5. & Occupation & $\begin{array}{l}\text { Agriculture + } \\
\text { Labour }\end{array}$ & 12 & 20.00 & 05 & 08.33 \\
\hline & & \begin{tabular}{|l|} 
Agriculture+ \\
Government / \\
Private services \\
\end{tabular} & 01 & 01.67 & 01 & 01.67 \\
\hline & & $\begin{array}{l}\text { No training } \\
\text { attended }\end{array}$ & 00 & 00.00 & 48 & 80.00 \\
\hline 6. & $\begin{array}{l}\text { Number of } \\
\text { trainings }\end{array}$ & One & 22 & 36.67 & 12 & 20.00 \\
\hline & attended & Two & 20 & 33.33 & 00 & 00.00 \\
\hline & & More than two & 18 & 30.00 & 00 & 00.00 \\
\hline & & $\begin{array}{l}\text { Low }(<\text { Rs. } \\
50,000)\end{array}$ & 16 & 26.67 & 20 & 33.33 \\
\hline 7. & Annual Income & \begin{tabular}{|l} 
Medium (Rs. \\
50,001 - Rs. \\
$1,00,000)$
\end{tabular} & 27 & 45.00 & 32 & 53.34 \\
\hline & & $\begin{array}{l}\text { High (>Rs. } \\
1,00,000) \\
\end{array}$ & 17 & 28.33 & 08 & 13.33 \\
\hline & & Low & 8 & 13.33 & 29 & 48.33 \\
\hline 8. & $\begin{array}{l}\text { Extension } \\
\text { participation }\end{array}$ & Medium & 41 & 68.34 & 21 & 35.00 \\
\hline & & High & 11 & 18.33 & 10 & 16.67 \\
\hline & & Low & 06 & 10.00 & 36 & 60.00 \\
\hline 9. & Progressiveness & Medium & 42 & 70.00 & 18 & 30.00 \\
\hline & & High & 12 & 20.00 & 06 & 10.00 \\
\hline
\end{tabular}




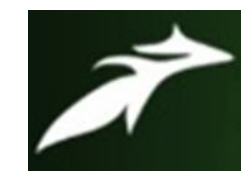

Ku. Sakshee Yadav et al, International Journal of Advances in Agricultural Science \& Technology, Vol.8 Issue.11, November-2021, pg. 60-69

ISSN: 2348-1358

Impact Factor: 6.057

NAAS Rating: 3.77

\begin{tabular}{|l|l|l|c|c|c|c|}
\hline & Low & 09 & 15.00 & 30 & 50.00 \\
\cline { 3 - 6 } 10. & \multirow{2}{*}{$\begin{array}{l}\text { Risk bearing } \\
\text { capacity }\end{array}$} & Medium & 39 & 65.00 & 26 & 43.33 \\
\cline { 3 - 7 } & High & 12 & 20.00 & 04 & 06.67 \\
\hline
\end{tabular}

The data presented in table 01 shows the distribution of trainee according to their age. Out of the total 120 respondents, higher percentage (65.00\%) were from middle age group. In the view of non-trainee, half $(50.00 \%)$ of the non-trainee belonged to middle age group. More than one third $(35.00 \%)$ of them were educated up to middle. Majority $(35.00 \%)$ of the non-trainee had not attain any education remained to be illiterate. Maximum number of respondents (trainee and non-trainee), 56.67 per cent and 50.00 per cent were marginal farmers. Hence, it can be concluded that majority of the farmers were marginal. Out of the total respondents (trainee), majority $(73.33 \%)$ had medium size of family. In non-trainee aspects, majority $(80.00 \%)$ had medium size of family. Higher percentage (73.33\%) of the respondents have doing agriculture alone as their occupation. Majority $(85.00 \%)$ of the non-trainee had agriculture alone as their profession. About 36.67 per cent trainee attended one training. About 20.00 per cent of the nontrainee has attended only one training programme rest 80.00 per cent of the non-trainee respondent did not attend any training programme. Nearly half $(45.00 \%)$ of the trainee and more than half $(53.34 \%)$ of the non-trainee were having annual income of fifty thousand one rupees to one lakh rupees. Majority 68.34 per cent trainee had medium extension participation. Higher percentage $(48.33 \%)$ of the non-trainee had low extension contact. Great majority $(70.00 \%)$ of the trainee had medium level of progressiveness. Majority (60.00\%) of the non-trainee had low level of progressiveness. Majority $(65.00 \%)$ of the trainee had medium level of risk bearing capacity. Half (65.00\%) of the non-trainee had low level of risk bearing capacity. 


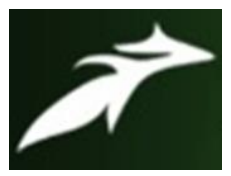

Ku. Sakshee Yadav et al, International Journal of Advances in Agricultural Science \& Technology,

Vol.8 Issue.11, November-2021, pg. 60-69

ISSN: 2348-1358

Impact Factor: 6.057

NAAS Rating: 3.77

Table 02: Association between the independent variables and income generation

\begin{tabular}{|c|l|c|}
\hline S. No. & \multicolumn{1}{|c|}{ Variable } & r value \\
\hline 1. & Age & $0.553^{*}$ \\
\hline 2. & Educational level & $0.610^{*}$ \\
\hline 3. & Land holding & $0.429^{*}$ \\
\hline 4. & Size of family & -0.027 \\
\hline 5. & Occupational status & 0.176 \\
\hline 6. & Number of trainings attended & $0.514^{*}$ \\
\hline 7. & Annual income & -0.035 \\
\hline 8. & Extension participation & 0.164 \\
\hline 9. & Progressiveness & $0.435^{*}$ \\
\hline 10. & Risk bearing capacity & 0.035 \\
\hline
\end{tabular}

* = Significant at $5 \%$

It could be understood from the table 03, that age, educational status, land holding, number of trainings attended and progressiveness had positive and significant association with the income generation of the trainee at 5 per cent level of probability. Meanwhile size of family, occupational status, annual income, extension participation and risk bearing capacity had nonsignificant association with the income generation of the trainee. The medium aged trainee who had middle school level education with marginal land holding attended more trainings with progressive nature had earned more income compared to others and non-trainee. 


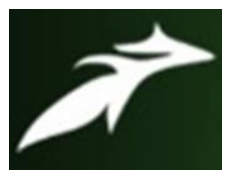

Ku. Sakshee Yadav et al, International Journal of Advances in Agricultural Science \& Technology,

Vol.8 Issue.11, November-2021, pg. 60-69

ISSN: 2348-1358

Impact Factor: 6.057

NAAS Rating: 3.77

Table 03: Table shows the Net Income of trainee in different activities:-

\begin{tabular}{|c|c|c|c|c|}
\hline \multirow{2}{*}{$\begin{array}{c}\text { S. } \\
\text { No. }\end{array}$} & \multirow{2}{*}{ Activities } & \multicolumn{3}{|c|}{ Net income (in Rupees) } \\
\cline { 3 - 5 } & & Low & Medium & High \\
\hline 1. & Dairy & $<3254$ & $3254-6153$ & $>6153$ \\
\hline 2. & Vegetable farming & $<4352$ & $4352-7353$ & $>7353$ \\
\hline 3. & $\begin{array}{c}\text { Mushroom } \\
\text { cultivation }\end{array}$ & $<2789$ & $2789-5893$ & $>5893$ \\
\hline 4. & Rope making & $<3698$ & $3698-5437$ & $>5437$ \\
\hline
\end{tabular}

The data of table 04 show the average net income earned by respondents from the aspects of vocational trainings. The respondents of dairy were earning higher average net income Rs.>6153, medium Rs. 3254-6153and low < 3254. The respondents vegetable farming were earning higher average net income Rs.> 7353, medium Rs. 4352 to 7353 and low <4352. The respondents of mushroom cultivation were earning higher average net income Rs.> 5893, medium Rs. 2789-5893 and low <2789. The respondents of rope making were earning higher average net income Rs.> 5437, medium Rs. 3698-5437and low <3698.

Table 04: Table shows the Net Income of non-trainee in different activities:-

\begin{tabular}{|c|c|c|c|c|}
\hline \multirow{2}{*}{ S. No. } & \multirow{2}{*}{ Activities } & \multicolumn{3}{|c|}{ Net income (in Rupees) } \\
\cline { 2 - 5 } & & Low & Medium & High \\
\hline 1. & Dairy & $<2864$ & $2864-5460$ & $>5460$ \\
\hline 2. & Vegetable farming & $<3940$ & $3940-6835$ & $>6835$ \\
\hline 3. & Mushroom cultivation & $<2500$ & $2500-5435$ & $>5435$ \\
\hline 4. & Rope making & $<3420$ & $3420-5267$ & $>5267$ \\
\hline
\end{tabular}




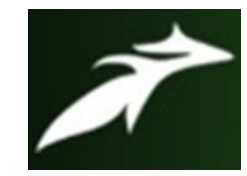

Ku. Sakshee Yadav et al, International Journal of Advances in Agricultural Science \& Technology, Vol.8 Issue.11, November-2021, pg. 60-69

ISSN: 2348-1358 Impact Factor: 6.057

NAAS Rating: 3.77

The data of table 05 show the average net income earned by respondents from the aspects of vocational trainings. The respondents of dairy were earning higher average net income Rs.>5460, medium Rs.2864-5460 and low <2864. The respondents vegetable farming were earning higher average net income Rs.> 6853, medium Rs. 3940-6835 and low <6835. The respondents of mushroom cultivation were earning higher average net income Rs.> 5435, medium Rs. 2500-5435 and low <2500. The respondents of rope making were earning higher average net income Rs.> 5267, medium Rs. 3420-5267 and low <3420.

Table 05: Distribution of trainee according to their income from vegetable farming

\begin{tabular}{|c|c|c|c|}
\hline \multirow{2}{*}{ S. No. } & \multirow{2}{*}{ Categories } & \multicolumn{2}{|c|}{ Respondents (n=22) } \\
\cline { 3 - 4 } & & Frequency & Percentage \\
\hline 1. & Low (Rs. <4352) & 02 & 09.10 \\
\hline 2. & Medium (Rs 4352 to 7353) & 14 & 63.63 \\
\hline 3. & High (Rs.>7353) & 06 & 27.27 \\
\hline \multicolumn{2}{|c|}{ Total } & 22 & 100 \\
\hline
\end{tabular}

Data of table 08 reveal that higher percentage $(63.33 \%)$ of the respondents were of medium income category, while 27.27 per cent and 09.10 per cent were of high and low income categories, respectively. Thus, it can be concluded that higher percentage of the respondents who were engaged in vegetable farming belonged to medium income category. 


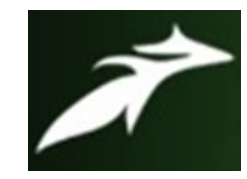

Ku. Sakshee Yadav et al, International Journal of Advances in Agricultural Science \& Technology, Vol.8 Issue.11, November-2021, pg. 60-69

ISSN: 2348-1358

Impact Factor: 6.057

NAAS Rating: 3.77

Table 06: Distribution of non-trainee according to their income from vegetable farming

\begin{tabular}{|c|c|c|c|}
\hline \multirow{2}{*}{ S. No. } & \multirow{2}{*}{ Categories } & \multicolumn{2}{|c|}{ Respondents $(\mathbf{n}=25)$} \\
\hline & & Frequency & Percentage \\
\hline 1. & Low (Rs.< 3940) & 11 & 44.00 \\
\hline 2. & Medium (Rs 3940-6835) & 13 & 52.00 \\
\hline 3. & High (Rs.>6835) & 01 & 04.00 \\
\hline & Total & 25 & 100 \\
\hline
\end{tabular}

Data of table 09 reveal that majority $(52.00 \%)$ of the non-trainee were of medium income category, while 44 per cent and 4 per cent were of high and low income categories, respectively. Thus, it can be concluded that higher percentage of the respondents who were engaged in vegetable farming belonged to medium income category but comparatively earned lower income than trainee.

\section{Conclusion:}

Most of the respondents belonged to medium socio-economic status. Majority of the trainees had undergone one day off campus training only. The trainees expressed that they need long duration on campus and vocational training. Hence, the subject matter specialists should look into the matter and organize such a type of training programmes. Information materials such as leaflets, pamphlets and books were found to be supplied to trainees occasionally or rarely in the present study. This factor must be taken care of and subject matter specialists should put more efforts to provide attractive and useful training material to their trainees at the time of training. Majority of trainees had favorable attitude towards KVK training programmes. Hence, there is a need on the part of subject matter specialists to educate and motivate the trainees about the benefits of latest agricultural technology through organizing KVK training programmes, 


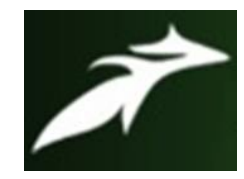

Ku. Sakshee Yadav et al, International Journal of Advances in Agricultural Science \& Technology, Vol.8 Issue.11, November-2021, pg. 60-69

ISSN: $2348-1358$

Impact Factor: 6.057

NAAS Rating: 3.77

demonstrations and exhibitions which in turn will help in developing more favorable attitude towards KVK training programmes.

\section{References}

[1]. Kailash, Mishra, O.P., Singh, S.K. and Verma, H. K. (2017). A study on socioeconomic impact of use the mobile phone technology among the farmers of Rajasthan state. Agric. Update, 12(3):454-458.

[2]. Manoj Kaur., Kanwaljit, Kaur and Kiranjot, Sindhu. 2019. Impact of Vocational Training Courses Conducted by Krishi Vigyan Kendras of Punjab on Establishing an Enterprise. Current Journal of Applied Science and Technology. 32(4): 1-8.

[3]. Pandey, A., Sarita Singh, S., Pandey, A., Gupta, N., and Bhargav, K.S. (2017). Adoption of Management Practices through to Dairy Farmers, Int. J. Pure App. Biosci. 5(1): 202206.

[4]. Panwar, A.S. 2018. Impact of Vocational Training Programme Conducted by KVK for Rural Women in Khandwa District of M.P., M.Sc. (Ag.) Thesis. Rajmata Vijayaraje Scindia Krishi Vishwa Vidhyala, Gwalior.

[5]. Safia, N.Ebrahim and V.Girija. 2020 Effectiveness of Home Science Vocational Training Programmes Imparted by KVKs, Journal of Extension Education, Vol.32.

[6]. Santhi, P., Sathyavathimuthu and Bhuvaneswari, K., (2013). Employment generating technology transfer by Krishi Vigyan Kendra as a means for empowering rural women. American Int. J.Res. Sci. Technol., Engineering Mathematics, 2(2): 213-219.

[7]. Singh, B., Meena, K. C., Vemra, S. R., and Meena, R. 2018. Impact of KVK,s training programmes on Guar (Cluster bean) production technology. International Journal of Agriculture Inovations and Research. 6(4): 89-91.

[8]. Sunil, N. K. and Manjula, N. (2010). Socio-economic, psychological and extension attributes of trained and untrained farmers of KVK, Bijapur. Agriculture Update, 5(1\&2): $38-42$. 